\title{
Health Disparities and Health Equity: a Health Care Educators' approach to Educating Nursing students
}

\author{
Jodi Dampeer Moore* \\ Department of Nursing, Delaware State University, Delaware, United States
}

Received: October 02, 2015; Accepted: December 24, 2015; Published: December 30, 2015

*Corresponding author: Jodi Dampeer Moore, Department of Nursing, Delaware State University, 1200 North DuPont Highway, Dover, Delaware 19901-2277, United States, Tel: +302-857-6754; E-mail: jdampeer@desu.edu

Obesity is becoming a global epidemic in both children and adults. The obesity rate in the US is currently $35.1 \%$ and cost the US 147 billion dollars in 2008 [1,2]. The group with the highest obesity rate in the US is the African American population which totals $47.8 \%[1,2]$. African American women hold the highest percentage at $58.5 \%$, [1,2]. Research shows there are several health related risks factors associated with obesity such as Cardiovascular Diseases (CVD), hypertension, and diabetes [36]. My research focus is on health disparities among African American.

While researching the obesity epidemic among the African American population and the contributing factors, it led to my research interest which examines the bias of health care workers towards obese clients. Most physicians and nurses are totally unaware they have biases. However, the client immediately recognizes that they are being treated negatively [7]. Research has shown that clients who have a negative experience with their physicians are reluctant to seek further care from that practitioner.

My research in this area explored the presence of implicit bias among nursing students and how it has an impact on health disparities. Much of the discussions about implicit bias and health disparities focuses on the clinician's attitudes and stereotypes about race [7-10]. In this study we measured the implicit and explicit bias in a cohort of senior nursing students' towards overweight and obese clients. The study found evidence of implicit bias against overweight and obese clients.

Health disparities among in the African American population. Eliminating racial health disparities is a goal of the US Department of Health and Human Services" Healthy People 2010 and 2020 initiates (DHHS, 2000; 2010). Racial disparities exist between African Americans and Caucasians and the leading cause of death in the US is cardiac disease [3-6,11]. Although there is an abundance of research on cardiovascular disease, there is a lack of research that examines how African Americans perceive these health inequities [11].

This study explored how African Americans identify health related risk factors and their assessment of acquiring cardiovascular disease. In the study, we varied the message content (neutral health topics only, Black-White cardiovascularrelated disparities and neutral health topics) embedded in a set of public serviceannouncement given to Black and White community members before completing a purported health self-assessment survey. The data suggest that exposure to comparative racial disparities messages concerning cardiovascular health inhibits the persistence of blacks and whites.

The goal of each of my research interest is to help eliminate health disparities, add body of knowledge and to use this information to educate my nursing students and future health care providers.

\section{References}

1. Center for Disease Control Prevention (CDC). Adult Obesity Causes -2015 update: Available at: http://www.cdc.gov/obesity/adult/ casues.html.

2. Ogden CL, Carroll MD, Kit BK, Flegal KM. Prevalence of childhood and adult obesity in the United States, 2011-2012. JAMA. 2014; 311(8): 806-14. doi: 10.1001/jama.2014.732.

3. Lloyd-Jones D, Adams RJ, Brown TM, Carnethon M, Dai S, De Simone G, et al. Heart disease and stroke statistics--2010 update: a report from the American Heart Association. Circulation. 2010; 121(7): e46-e215. doi: 10.1161/CIRCULATIONAHA.109.192667.

4. Go AS, Mozaffarian D, Roger VL, Benjamin EJ, Berry JD, Borden WB, et al. Heart disease and stroke statistics-2013 update: A report from the American Heart Association. Circulation. 2013; 127(1): e6-e245. doi: 10.1161/CIR.0b013e31828124ad.

5. Ostfeld A, Barry L Zaret, Lawrence S Cohen, Marvin Moser. Chapter 22: Racial and ethnic differences in heart disease. Yale University School of Medicine Heart Book. New York: Hearst Books. 1992: 273-280.

6. Roger VL, Go AS, Lloyd-Jones DM, Benjamin EJ, Berry JD, Borden WB, et al. Heart disease and stroke statistics- 2012 update: A report from the American Heart Association. Circulation. 2012; 125(1): e2-e220. doi: 10.1161/CIR.0b013e31823ac046.

7. Sabin JA, Rivara FP, Greenwald AG. Physician implicit attitudes and stereotypes about race and quality of medical care. Med Care. 2008; 46(7): 678-85. doi: 10.1097/MLR.0b013e3181653d58. 
8. Sabin J, Nosek BA, Greenwald A, Rivara FP. Physicians' implicit and explicit attitudes about race by MD race, ethnicity, and gender. J Health Care Poor Underserved. 2009; 20(3): 896-913. doi: 10.1353/ hpu.0.0185.

9. White-Means S, Zhiyong Dong, Hufstader M, Brown LT. Cultural competency, race, and skin tone bias among pharmacy, nursing, and medical students: implications for addressing health disparities. Med Care Res Rev. 2009; 66(4): 436-55. doi: 10.1177/1077558709333995.
10. Penner LA, Dovidio JF, West TV, Gaertner SL, Albrecht TL, Dailey RK, et al. Aversive racism and medical interactions with black patients: a field study. J Exp Soc Psychol. 2010; 46(2): 436-440.

11. Jones PR, Taylor DM, Dampeer-Moore J, Van Allen KL, Saunders DR, Snowden CB, et al. Health-Related Stereotype Threat Predicts Health Services Delays Among Blacks. Race Soc Probl. 2013; 5(2): 121-136. 